\section{Recombinant DNA risk-assessment studies to begin at Fort Detrick}

EXPERIMENTS designed to investigate the potential risks of recombinant DNA research are soon to begin in newly-converted, top-level containment laboratories at Fort Detrick, Maryland, until recently the Defense Department's centre for research into chemical and biological weapons.

The experiments will focus on the possible conversion of non-pathogenic bacteria and viruses to virulent forms by insertion of foreign DNA segments, and are being carried out by Dr Wallace Rowe and Dr Malcolm Martin of the National Institute of Allergy and Infectious Diseases.

In particular, DNA taken from mouse polyoma virus will be inserted into Escherichia coli, and the bacteria subsequently introduced into mice to see if any neoplasms develop. Such a risk-assessment experiment was first suggested at a meeting in California two years ago by Dr Sidney Brenner of the Medical Research Council's Molecular Biology Laboratory in Cambridge, England.

Similar experiments are already under way at the UK Ministry of Defence's Microbiological Research Establishment at Porton Down. However, the US scientists hope that their greater familiarity with animal experiments will help compensate for an early lead established by their European colleagues.

The opening of the Fort Detrick laboratory-which has been accepted by the National Institutes of Health as meeting the $\mathrm{P} 4$ level of physical

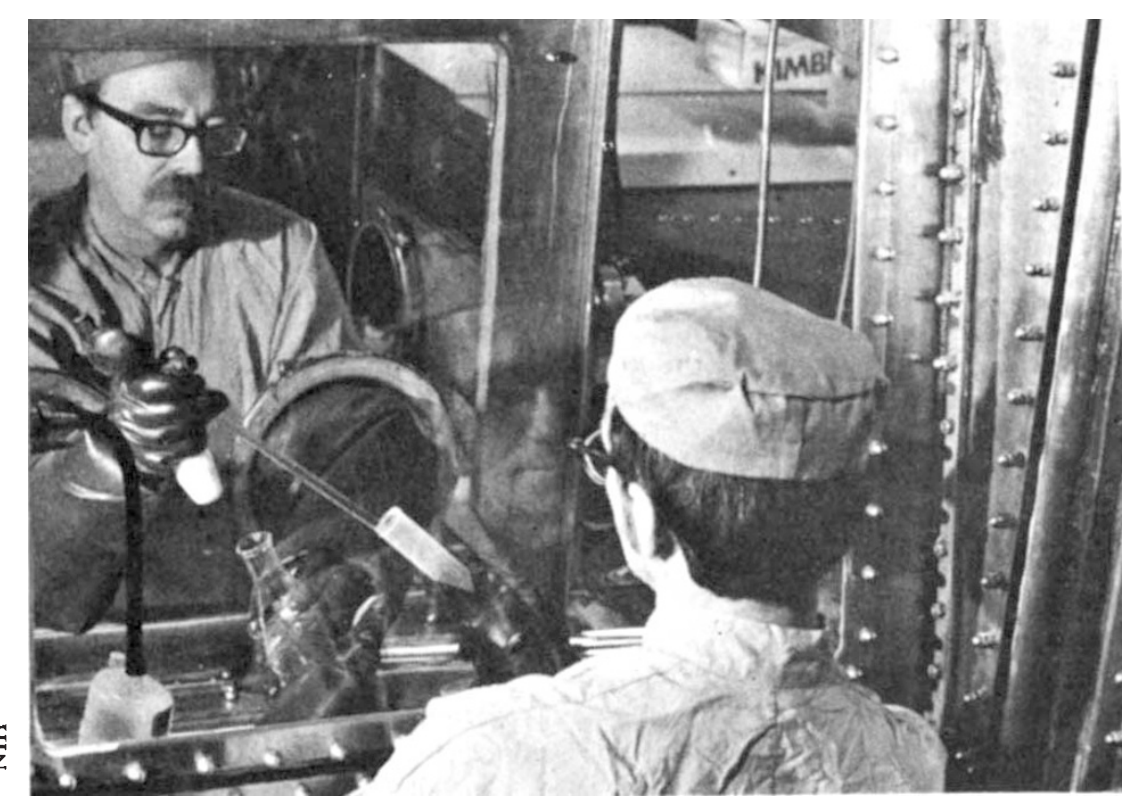

Research in progress at Fort Detrick's $P-4$ facilities

containment-and the beginning of the Rowe-Martin experiment, had been held up by a suit brought by a local lawyer, Mr Ferdinand Mack, on behalf of his $2 \frac{1}{2}$-year-old son.

Earlier this month, however, a US District Court judge dismissed $\mathrm{Mr}$ Mack's claims that the experiments represented an unacceptable gamble.

Dr Martin said last week that the experiments would begin as soon as a one-week dry-run of the laboratory designed to test its safety precautions had been completed, and that he expected the first results within three to five months. "We have been endeavouring to get this experiment under way for quite a while, and I am looking forward with great eagerness to getting things started," Dr Martin said.

The Fort Detrick laboratory, which is now run by the Frederick Cancer Research Center and was converted at a cost of $\$ 250,000$, is described as an interim facility. Plans have been drawn up for a permanent national P4 facility on the same site which is expected to be in opcration in the middle of 1979; other P4 facilities are also being built by the National Institutes of Health in Bethesda.

Dr John Nutter, chief of the NIAID's Office of Specialised Research and Facilities, said last week that the facilities will be reserved for the Rowe. Martin experiments for between four and six months. After this period the laboratory will become available for visitor research, and applications would be invited from other scientists wishing to use the facility, Dr Nutter said.

David Dickson

\title{
University patent rights on research: US thinks again
}

THE US Government has agreed to delay the introduction of a new regulation which would grant universities the patent rights on almost all inventions developed in the course of federallyfunded research, a move which opponents claim to be unconstitutional and "contrary to the public interest".

The new rule was published by the General Services Administration in the Federal Register at the beginning of February, and was to have come into effect last week. However the GSA has agreed to defer the rule for a period of 120 days at the request of the Office of Management and Budget, itself under pressure from the Senate Subcommittee on Small Businesses.

Under the proposed regulation, universities and non-profit institutions would, subject to certain conditions, be allowed to retain the entire right, title and interest in patents on inventions made in the course of federally-funded contracts.

Such an arrangement would be covered by an Institutional Patent Agreement of the form which is already applied to federally-funded research carried out in other sectors, and to university research sponsored by the Department of Health Education and Welfare.

The new rules are in line with a recommendation made by the Committee on Intellectual Property and Information of the Federal Co-ordinating Council for Science Engineering and Technology. However, it is being challenged by those who claim that it would lead to a sacrifice by the government of large potential income.
In a letter to the administrator of the GSA, Mr Jay Solomon, consumer advocate Ralph Nader and an associate, Dr Sidney Wolfe, claim the policy to be particularly undesirable in giving away patents whose nature, utility and value are unknown at the time of disposal.

"If this policy is implemented, it is likely that. over the next decade, these institutions will reap hundreds of millions of dollars of profits from work supported by the federal government," the critics claim. "We believe that such a policy is unconstitutional, unwise and contrary to the public interest."

The proposed rules will be the subject of a three-day hearing planned to be held next month by the Senate Committee on Small Businesses, under the chairmanship of Senator Gaylord Nelson. 